\title{
SUMMARY OF THESIS*
}

BRAZ, Lúcia Maria de Almeida - Comparação da Reação em Cadeia da Polimerase com o exame microscópico na detecção do Trypanosoma cruzi em amostras procedentes do trato digestório do Triatoma infestans. São Paulo, 2006. (Tese de doutoramento - Faculdade de Medicina da Universidade de São Paulo.

\section{COMPARISON OF POLYMERASE CHAIN REACTION WITH MICROSCOPIC EXAMINATION TO DETECT Trypanosoma cruzi IN Triatoma infestans DIGESTIVE TRACT SAMPLES}

Immunosuppressed patients may experience episodes of Chagas disease reactivation with negative direct parasitological investigation. In this situation xenodiagnosis is recommended, even though this technique depends very much on the biologist's background to detect T. cruzi under microscopic examination and demands 30 to 60 days. Polymerase Chain Reaction (PCR) has been used to increase sensitivity of xenodiagnosis. The present study has aimed at comparing detection of T.cruzi in T. infestans digestive tract samples by PCR and microscopic examination (ME) performed in the context of xenodiagnosis, at different times after bugs feeding in Balb/C mice experimentally infected by T.cruzi, and divided in two groups: with high parasitemia and with low parasitemia. Representing the first group, 110 triatomines were divided in 11 groups of 10 triatomines each, and fed in Balb/C mice presenting with high parasitemia of T.cruzi. As controls, 110 triatomines were divided in 11 groups of 10 insects each, and were fed in non infected mice. The second group was composed of 220 triatomines divided in 11 groups of 20 triatomines each and fed in mice presenting low parasitemia of T.cruzi. As controls, 55 triatomines were divided in 11 groups of five insects each, and were fed in non infected mice. Samples of all triatomines of each group were examined on the $1^{\text {st }}, 2^{\text {nd }}, 3^{\text {rd }}, 4^{\text {th }}, 5 \mathrm{t}^{\mathrm{h}}, 10^{\text {th }}, 15^{\text {th }}, 20^{\text {th }}, 25^{\text {th }}, 30^{\text {th }}$ and $60^{\text {th }}$ day after feeding. Samples were separated in two aliquots: the first one was examined by ME and the second one by PCR. Amplifications were performed with a new pair of primers from the genomic TCZ sequence of T.cruzi. Results showed that all samples from control triatomines were negative by both methods. On the $1^{\text {st }}, 2^{\text {nd }}, 3^{\text {rd }}, 4^{\text {th }}, 5^{\text {th }}, 10^{\text {th }}, 15^{\text {th }}$, $20^{\text {th }}, 25^{\text {th }}, 30^{\text {th }}$ and $60^{\text {th }}$ day, of the high parasitemia model, results were: $75 \%, 60 \%, 50 \%, 40 \%, 60 \%, 90 \%, 100 \%, 88.9 \%, 88.9 \%, 100 \%$ and $90 \%$ of positivity by PCR; and $50 \%, 30 \%, 30 \%, 40 \%, 30 \%, 60 \%$, $50 \%, 55.6 \%, 33.3 \%, 70 \%$ and $20 \%$ by ME, respectively. In the low parasitemia model, on the $1^{\text {st }}$ day, only PCR was positive in $40 \%$ of cases and on the $2^{\text {nd }}, 3^{\text {rd }}, 4^{\text {th }}, 5^{\text {th }}, 10^{\text {th }}, 15^{\text {th }}, 20^{\text {th }}, 25^{\text {th }}, 30^{\text {th }}$ and $60^{\text {th }}$ day, PCR presented positivity of $55 \%, 40 \%, 70 \%, 63 \%, 60 \%, 65 \%, 52.6 \%$, $60 \%, 78.9 \%$ and $68.4 \%$; and by ME $5 \%, 5 \%, 15 \%, 15.8 \%, 25 \%, 25 \%$, $31.6 \%, 30 \%, 36.8 \%$ and $36.8 \%$, respectively. The statistical analysis made by means of the McNemar procedure showed discordances among results obtained by PCR and ME. This difference was statistically significant $(p<0.05)$, thus indicating superiority of PCR with respect to ME. We concluded that the PCR technique presented with advantages to Chagas disease diagnosis when compared to $\mathrm{ME}$, as a complementary test of xenodiagnosis, in 10 of 11 times in the high parasitemia model, and in all study times in the low parasitemia model. Considering that the low parasitemia model resembles the situation found in immunosuppressed patients with reactivation of Chagas disease, this finding is of clinical relevance as it may influence medical decisions and the prognosis of those patients.

Lucia Maria de Almeida Braz lmabraz@usp.br 